\title{
Effect of chemical agents, metallic salts on the stability of $\alpha$-amylase, protease and comparative analyses of enzyme activity of selected salad vegetables
}

\author{
${ }^{1}$ Rahman, M.M., ${ }^{1 * *}$ Shahjadee, U.F., ${ }^{2}$ Khanam, F., ${ }^{1}$ Rupa, A.Z. and ${ }^{2}$ Azad, M.A.K. \\ ${ }^{1}$ Institute of Food Science and Technology (IFST), Bangladesh Council of Scientific and \\ Industrial Research (BCSIR), Dhaka-1205, Bangladesh \\ ${ }^{2}$ Department of Biotechnology and Genetic Engineering, Islamic University, Kushtia-7003, \\ Bangladesh
}

\section{Article history: \\ January 2020 2020 \\ Keywords: \\ Salad vegetables, \\ Enzymes activity, \\ Chemical agent, \\ Metallic salts, \\ Stability}

Received: 18 July 2019

Received in revised form: 30

Accepted: 9 February 2020

Available Online: 9 March

\section{DOI:}

https://doi.org/10.26656/fr.2017.4(4).259

\begin{abstract}
The present investigation was conducted to analyze the activity of enzymes (protease, $\alpha$ amylase, cellulase and urease) of selected salad vegetables (white radish, red radish, beet, carrot, papaya, cucumber and tomato) as well as to determine the effect of chemical agents and metallic salts on the stability of enzymes. Salad vegetables are one of the cheap sources of adequate vitamins, minerals and enzymes. The protease, $\alpha$-amylase and cellulase activity were highest in papaya $(4.11 \pm 0.21 \mathrm{U} / \mathrm{g}, 1.68 \pm 0.21 \mathrm{U} / \mathrm{g}$ and $0.26 \pm 0.13 \mathrm{U} /$ g) whereas the urease activity was not detected in papaya, cucumber and tomato. The protease, $\alpha$-amylase and cellulase activity of papaya were increased $24.83 \%, 42.26 \%$ and $57.69 \%$ than cucumber while the cellulase activity of carrot was increased $44.45 \%$ than tomato. The activity of protease and $\alpha$-amylase of beet were decreased $52.44 \%, 33.63 \%$ while the cellulase activity of beet was increased $36.36 \%$ from radish. The toxicity indicating urease enzyme activity was not detected in papaya, tomato and cucumber but negligible in radish, beet and carrot which can be nullified. The activities of enzymes were increased in the presence of metallic salts such as $\mathrm{Ca}^{2+}, \mathrm{Mg}^{2+}$ and $\mathrm{Mn}^{2+}$ while $\mathrm{Fe}^{2+}, \mathrm{Zn}^{2+}$ and $\mathrm{Cu}^{2+}$ inhibited the enzyme's activity moderately. Results revealed that in the presence of higher concentrations of urea, EDTA and acetic acid, the activities of all the enzymes were completely inhibited.
\end{abstract}

\section{Introduction}

Salad vegetables are an essential part of people's diet all around the world. They are usually consumed as raw or cooking. Vegetable salad is a very common food accompaniment. The vegetables that usually make up these salad items include carrot, cucumber, tomato, papaya, beet and radish (Itohan et al., 2011). Carrot, cucumber, tomato, papaya, beet and radish are a versatile vegetable that may be consumed raw, cooked or in combination with other vegetables and meats in salads, freshly prepared foods and frozen prepared foods. Fruits and vegetables have health benefits for consumers, due to their content of fiber, vitamins and antioxidant compounds. However, for the antioxidant compounds, many changes occur during harvesting, preparation (fresh-cut fruits) and storage of these fruits. These changes induce a pronounced loss of microbiological and antioxidant qualities (Lindley, 1998). Fresh fruits and vegetables provide mankind with an abundance of benefits. These play an important role in health and have the ability to prevent many diseases such as heart disease, cancers and diabetes (Liu, 2004; Pandey, et al., 2006). The highly soluble minerals like calcium, phosphorus, iron, magnesium, copper, and potassium contained in vegetables maintain the acid/base balance of hydrogen concentration of body tissues. These help to completely absorb the vitamins, proteins, fats and carbohydrates of the food (Odoh and Okoro, 2012).

The World Health Organization (WHO) (1989) recommends the consumption of at least five $100 \mathrm{~g}$ portions of fruits and vegetables daily to stay healthy. Health nutrition specialists recommend adding to everyday diet as much as possible fruits and vegetables although the general public has a limited understanding of what the real benefits are, or how much should be eaten. Current recommendations are that adults should consume at least $400 \mathrm{~g}$ (or five servings a day) of fruits and vegetables (WHO, 1989). The nutritional analysis of edible fruit and vegetables plays a crucial role in the assessment of nutritional significance. A comprehensive survey was conducted by an extensive tour throughout the selected locations during both winter and summer 
seasons from April 2010 to December 2012. In the selected locations two or more vegetables are grown every year (Khan et al., 2010). Vegetables are richer in mineral substances as compared with fruits. Enzymes enter into a vast number of biochemical reactions in fruits and vegetables, they may be responsible for changes in flavor, color, texture and nutritional properties. In fruit and vegetable storage and processing, the most important roles are played by the enzymes classes of hydrolyses (invertase, protease, amylase, cellulase) (Enacheshu, 1995). Salad vegetables are one of the cheap sources of adequate vitamins, minerals and enzymes.

Data available on the biochemical parameters of radish produced in Bangladesh are quite scanty. Only limited work has been done on the physiochemical properties of tomato, papaya, cucumber and carrot. Some works have been going on at Bangladesh Agricultural Research Institute (BARI) with emphasis on the higher production and development of new varieties and control of the diseases. No detail work has been done on the chemical composition and enzyme activities in tomato, papaya, cucumber and carrot. Enzymes have become a powerful catalytic tool in a wide variety of chemical processes. Higher plants play an important role as a source of many useful enzymes. Extensive use of enzyme activity determination as an aid to the diagnosis in hospital and laboratories all over the world is one of the dramatic developments in modern medicine (Jahan et al., 2011). The present study is, therefore, designed to study the activities of different enzymes and also to determine the chemical agents and metallic salts on the stability of the enzymes of selected salad vegetables.

\section{Materials and methods}

\subsection{Collection of samples}

Samples were collected directly from the cultivated field of the local area in the winter season.

\subsection{Enzyme activity assay}

Fresh healthy samples were washed thoroughly with distilled water, cut into small pieces and peste in a mortar at $4^{\circ} \mathrm{C}$ with cold $0.1 \mathrm{M}$ phosphate buffer of respective $\mathrm{pH}$, for amylase 6.7 , for protease citrate buffer, 5.5, for urease $0.2 \mathrm{M}$ phosphate buffer, 7.0 for cellulase $0.2 \mathrm{M}$ sodium acetate buffer, 5.2. The extracts were filtered with few layers of cheesecloth and further clarified by centrifugation at $10,000 \mathrm{rpm}$ for $15 \mathrm{mins}$ at $4^{\circ} \mathrm{C}$. The clear supernatant was collected and used as a crude enzyme extract.

\subsection{Assay of $\alpha$-amylase activity}

Amylase activity was assayed following the method as described by Jayaraman (1981). A total of 1\% starch solution was used as the substrate $(1.0 \mathrm{~g}$ in $100 \mathrm{~mL}$ of $0.1 \mathrm{M}$ phosphate buffer, $\mathrm{pH}$ 6.7). The amylase activity was measured by estimating the release of maltose. The amount of maltose released was calculated from the standard curve prepared with maltose. One unit of amylase activity was defined as the amount required for liberating $1 \mathrm{mg}$ of maltose in $15 \mathrm{mins}$ at $37^{\circ} \mathrm{C}$.

\subsection{Assay of protease activity}

Protease activity was assayed following the modified method as described by Mahadevan and Sridhar (1982). Haemoglobin was used as substrate. The protease activity was measured by estimating the amount of leucine released from haemoglobin. The amount of leucine released was calculated from the standard curve prepared with leucine. One unit of protease activity was defined as the amount required for liberating $1 \mathrm{mg}$ of leucine in 30 mins at $37^{\circ} \mathrm{C}$.

\subsection{Assay of cellulase activity}

Cellulase activity was measured following the method described by Mahadevan and Sridhar (1982). Carboxymethyl cellulose (CMC) was used as substrate. Cellulase activity was measured by estimating the reducing sugar released from the substrate using the DNS method. One unit of cellulase activity was defined as the amount of enzyme required for liberating $1 \mathrm{mg}$ of reducing sugar from $\mathrm{CMC}$ per minute at $37^{\circ} \mathrm{C}$.

\subsection{Assay of urease activity}

Urease activity was assayed following the method as described by Jayaraman (1981). A total of 3\% urea solution was used as substrate $(1 \mathrm{~g}$ in $100 \mathrm{~mL}$ of $0.2 \mathrm{M}$ phosphate buffer, $\mathrm{pH}$ 7.0). The Urease activity was measured by estimating the release of ammonium. The amount of ammonium released was calculated from the standard curve prepared with ammonium. One unit of Urease activity was defined as the amount required for liberating $1 \mu \mathrm{g}$ of ammonium in $15 \mathrm{mins}$ at $55^{\circ} \mathrm{C}$.

\subsection{Effect of chemical agents and metallic salts}

Treatment with $\mathrm{CaCl}_{2}$, urea, acetic acid, EDTA and various metallic salts at different concentrations were added to $5.0 \mathrm{~mL}$ of amylase, protease, cellulase and urease enzymes extract solutions from salad vegetables and incubated for $10 \mathrm{mins}$ at $20^{\circ} \mathrm{C}$. The mixtures were again incubated with the substrate for $15 \mathrm{mins}$ at $37^{\circ} \mathrm{C}$ and the enzyme activities were assayed (Rahman, 2001).

\subsection{Statistical analysis}

Each experiment was replicated three times. 
Reported data represented as mean values \pm SD obtained from three individual experiments. Data were subjected to analysis of variance using the Microsoft Excel Program (Redmond, Washington DC, USA).

\section{Results and discussion}

\subsection{Enzymes activity}

Vegetables are very rich sources of essential biochemicals and nutrients such as vitamins, minerals and enzymes which are the major portion of the human diet. The results of protease and $\alpha$-amylase activity are shown in Table 1 . The protease activity of white radish, red radish, beet, carrot, papaya, cucumber and tomato were $1.99 \pm 0.20(\mathrm{U} / \mathrm{g}), 2.44 \pm 1.00(\mathrm{U} / \mathrm{g}), 1.16 \pm 0.16(\mathrm{U} / \mathrm{g})$, $2.55 \pm 0.19(\mathrm{U} / \mathrm{g}), 4.11 \pm 0.20(\mathrm{U} / \mathrm{g}), 1.18 \pm 0.21(\mathrm{U} / \mathrm{g})$ and $2.85 \pm 0.22(\mathrm{U} / \mathrm{g})$ respectively (Table 1$)$. The maximum protease activity was found in papaya $4.11 \pm 0.20(\mathrm{U} / \mathrm{g})$ and minimum in beet $1.16 \pm 0.16(\mathrm{U} / \mathrm{g})$. The protease activity of papaya $0.72-3.11(\mathrm{U} / \mathrm{g})$ which was slightly lower than the investigation (Xiang-dong et al., 2006).

The papaya showed maximum $\alpha$-amylase activity than beet. Results of the present study are in accordance with the findings with some researchers in the case of vegetables (Ajayi et al., 2011). The cellulase activity of white radish, red radish, beet, carrot, papaya, cucumber and tomato were $0.14 \pm 0.07(\mathrm{U} / \mathrm{g}), 0.072 \pm 0.012(\mathrm{U} / \mathrm{g})$,

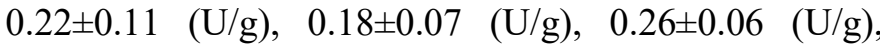
$0.11 \pm 0.03(\mathrm{U} / \mathrm{g})$, and $0.10 \pm 0.05 \quad(\mathrm{U} / \mathrm{g})$ respectively (Table 1). Salad vegetables have a poor amount of protein and carbohydrate contents. That's why the enzyme protease and $\alpha$-amylase show fewer assay results.

The highest cellulase activity was found in papaya $(0.26 \pm 0.06 \mathrm{U} / \mathrm{g})$ and the lowest was in red radish $(0.072 \pm 0.012 \mathrm{U} / \mathrm{g})$. Tomato showed lowest $(9.09 \%)$ cellulase activity than cucumber among the salad variety. These findings are in close agreement with the researchers who revealed the low cellulase activity in tomato (Wilson, 2012). Besides, the highest cellulase activity was $57.69 \%$ in papaya than cucumber. The urease activity of white radish, red radish, beet, carrot, papaya, cucumber and tomato were $0.067 \pm 0.10(\mathrm{U} / \mathrm{g})$, $0.061 \pm 0.25(\mathrm{U} / \mathrm{g}), 0.081 \pm 0.10(\mathrm{U} / \mathrm{g}), 0.018 \pm 0.09(\mathrm{U} / \mathrm{g})$ respectively (Table 1 ). The urease activity of papaya, cucumber and tomato were not detected. The $\alpha$-amylase activity of carrot was $0.18 \pm 0.15(\mathrm{U} / \mathrm{g})$. The cause may be the presence of urease activity in carrot the utilization of nitrogen fertilizer in cultivating soil. Besides this, the results showed no presence of urease activity in carrot in his research work (Richard and Michael, 1973). Urea was found naturally in the environment and is also artificially introduced, comprising more than half of all synthetic nitrogen fertilizers used globally. For this reason, the negligible amount of urease activity was found in radish, beet and carrot (Nowak et al., 2003).

\subsection{Effect of calcium on the activities of $\alpha$-amylase and protease}

The effect of calcium as metallic salt on the activities of $\alpha$-amylase and protease is presented in Table 2. The activities of enzymes were gradually increased with the increasing concentration of calcium and in the presence of $0.50 \mathrm{M} \mathrm{Ca}^{2+}$, the activities of $\alpha$-amylase and protease became $135.24 \%$ and $129.46 \%$ respectively.

Table 2. Effect of calcium on the activities of $\alpha$-amylase and protease

\begin{tabular}{ccc}
\hline \multirow{2}{*}{ Concentration of $\mathrm{CaCl}_{2}$ (Molar) } & \multicolumn{2}{c}{ Relative activities (\%) } \\
\cline { 2 - 3 } & $\alpha$-amylase & Protease \\
\hline 0.000 & 100.00 & 100.00 \\
0.001 & 104.36 & 105.66 \\
0.005 & 107.18 & 108.34 \\
0.010 & 113.35 & 112.68 \\
0.050 & 117.38 & 116.38 \\
0.300 & 130.24 & 123.65 \\
0.500 & 135.34 & 129.46 \\
\hline
\end{tabular}

\subsection{Activities of the enzymes after treatment with different concentration of urea}

Table 3 shows the relatives activities of the enzymes after treatment with different concentration of urea. The activities of the $\alpha$-amylase and protease were found to be decreased remarkably in the presence of urea

Table 1. Protease, $\alpha$-amylase, cellulase and urease activities of white radish, red radish, beet, carrot, papaya, cucumber and tomato.

\begin{tabular}{ccccc}
\hline \multirow{2}{*}{ Name of samples } & \multicolumn{4}{c}{ Enzymes activity } \\
\cline { 2 - 5 } & Protease $(\mathrm{U} / \mathrm{g})$ & $\alpha$-amylase $(\mathrm{U} / \mathrm{g})$ & Cellulase $(\mathrm{U} / \mathrm{g})$ & Urease $(\mathrm{U} / \mathrm{g})$ \\
\hline White Radish & $1.99 \pm 0.20$ & $1.47 \pm 0.20$ & $0.14 \pm 0.07$ & $0.067 \pm 0.10$ \\
Red Radish & $2.44 \pm 1.00$ & $1.10 \pm 0.21$ & $0.072 \pm 0.012$ & $0.061 \pm 0.25$ \\
Beet & $1.16 \pm 0.16$ & $0.73 \pm 0.10$ & $0.22 \pm 0.11$ & $0.081 \pm 0.10$ \\
Carrot & $2.55 \pm 0.19$ & $1.56 \pm 0.18$ & $0.18 \pm 0.07$ & $0.018 \pm 0.09$ \\
Papaya & $4.11 \pm 0.20$ & $1.68 \pm 0.23$ & $0.26 \pm 0.06$ & Not detected \\
Cucumber & $1.18 \pm 0.21$ & $0.97 \pm 0.20$ & $0.11 \pm 0.03$ & Not detected \\
Tomato & $2.85 \pm 0.22$ & $1.52 \pm 0.22$ & $0.10 \pm 0.05$ & Not detected \\
\hline
\end{tabular}

The values are mean $\pm \mathrm{SD}$ of determinations made in triplicate 
and at $6 \mathrm{M}$ urea concentration. Protease and $\alpha$-amylase decreased by about $88 \%$ and $79 \%$ respectively.

Table 3. Effect of urea on the activities of $\alpha$-amylase and protease

\begin{tabular}{ccc}
\hline \multirow{2}{*}{ Concentration of urea (Molar) } & \multicolumn{2}{c}{ Relative activities (\%) } \\
\cline { 2 - 3 } & $\alpha$-amylase & Protease \\
\hline 0 & 100.00 & 100.00 \\
1 & 95.17 & 91.62 \\
2 & 82.41 & 75.78 \\
4 & 46.82 & 41.76 \\
6 & 22.64 & 13.35 \\
8 & 0.00 & 0.00 \\
\hline
\end{tabular}

3.4 Activities of $\alpha$-amylase and protease after treatment with different concentration of EDTA

The relative activities of $\alpha$-amylase and protease in the presence of different concentrations of EDTA are presented in Table 4 . The activities of $\alpha$-amylase and protease are abolished gradually with the increase of EDTA concentrations and the enzymes lost their activities completely in the presence of 0.50M EDTA.

Table 4. Effect of EDTA on the activities of $\alpha$-amylase and protease

\begin{tabular}{ccc}
\hline \multirow{2}{*}{ Concentration of EDTA (Molar) } & \multicolumn{2}{c}{ Relative activities (\%) } \\
\cline { 2 - 3 } & $\alpha$-amylase & Protease \\
\hline 0.000 & 100.00 & 100.00 \\
0.001 & 85.34 & 76.69 \\
0.005 & 67.29 & 59.82 \\
0.010 & 53.22 & 47.34 \\
0.100 & 34.46 & 27.64 \\
0.300 & 15.60 & 13.36 \\
0.500 & 0.00 & 0.00 \\
\hline
\end{tabular}

3.5 Activities of $\alpha$-amylase and protease after treatment with different concentration of acetic acid

As shown in Table 5, the activities of the enzymes were gradually decreased with the treatment of higher percentage of acetic acid. It is found that $\alpha$-amylase and protease retained $22.43 \%$ and $19.17 \%$ after treatment with $20 \%$ acetic acid. Overall, the effect of calcium, urea, EDTA and acetic decrease the enzyme's activity which is partially in agreement with Akand (2003) and Haque et al. (2017)

Table 5. Effect of acetic acid on the activities of $\alpha$-amylase and protease

\begin{tabular}{ccc}
\hline \multirow{2}{*}{ Concentration of acetic acid (\%) } & \multicolumn{2}{c}{ Relative activities (\%) } \\
\cline { 2 - 3 } & $\alpha$-amylase & Protease \\
\hline 0.00 & 100.00 & 100.00 \\
2.50 & 90.16 & 89.53 \\
5.00 & 75.33 & 75.89 \\
10.00 & 46.65 & 47.20 \\
20.00 & 22.43 & 19.17 \\
30.00 & 0.00 & 0.00 \\
\hline
\end{tabular}

3.6 Effect of metallic salts on the activities of $\alpha$-amylase and protease

Table 6 represents the effect of various metallic salts on the activities of $\alpha$-amylase and protease. The activities of enzymes were increased remarkably in the presence of $\mathrm{Mn}^{2+}$ salts while that was increased slightly in the presence of $\mathrm{Mg}^{2+}$ salts. Other metallic salts such as $\mathrm{K}^{2+}$ and $\mathrm{Na}^{2+}$ produce little or no inhibitory on the activities of the enzymes but the activities of all the enzymes reduce significantly in the presence of $\mathrm{Zn}^{2+}, \mathrm{Cu}^{2+}$ and $\mathrm{Fe}^{2+}$.

Table 6. Effect of various metallic salts on the activities of $\alpha$ amylase and protease.

\begin{tabular}{cccc}
\hline \multirow{2}{*}{ Test Salts } & $\begin{array}{c}\text { Concentration } \\
\text { (Molar) }\end{array}$ & \multicolumn{2}{c}{ Relative activities (\%) } \\
\cline { 3 - 4 } None & - & 100.00 & 100.00 \\
& 0.001 & 105.72 & 106.01 \\
$\mathrm{MgCl}_{2}$ & 0.002 & 108.32 & 109.12 \\
& 0.001 & 85.24 & 93.26 \\
$\mathrm{ZnCl}_{2}$ & 0.002 & 73.21 & 86.55 \\
& 0.001 & 86.71 & 71.84 \\
$\mathrm{CuCl}_{2}$ & 0.002 & 76.36 & 53.64 \\
& 0.001 & 117.73 & 113.42 \\
$\mathrm{MnCl}_{2}$ & 0.002 & 127.63 & 121.66 \\
& 0.001 & 100.00 & 99.72 \\
$\mathrm{NaCl}_{2}$ & 0.002 & 99.78 & 99.98 \\
& 0.001 & 100.00 & 100.00 \\
$\mathrm{KCl}_{2}$ & 0.002 & 100.00 & 100.00 \\
& 0.001 & 73.16 & 67.28 \\
$\mathrm{FeCl}_{2}$ & 0.002 & 589.44 & 53.20 \\
\hline
\end{tabular}

The activity of $\alpha$-amylase and protease were abolished completely by denaturing agents $8.0 \mathrm{M}$ urea. These denaturing agents may destroy the secondary or tertiary structure of the enzymes this results in complete destruction of the active enzyme at higher concentration (Rahman, 2001; Haque et al., 2017).

The activities of the enzymes increased significantly in the presence of divalent cation $\mathrm{Ca}^{2+}$ and $\mathrm{Mn}^{2+}$ suggesting the involvement of these divalent ions in maintaining the active conformation of the enzymes. Other metallic salts such as $\mathrm{K}^{2+}$ and $\mathrm{Na}^{2+}$ produce little or no inhibitory on the activities of the enzymes but the activities of all the enzymes reduce significantly in the presence of $\mathrm{Zn}^{2+}, \mathrm{Cu}^{2+}$ and $\mathrm{Fe}^{2+}$ (Akand, 2003; Haque et al., 2017).

\section{Conclusion}

It was aimed to evaluate the enzymatic activity ( $\alpha$ amylase, urease, cellulase and protease) of white radish, 
red radish, beet, carrot, papaya, cucumber and tomato with each other. It was found that the enzymes' activity was different in all the selected salad vegetables its play an important role in the metabolic function of the human body. Through this research work, the enzymatic activity of salad vegetables was determined. Moreover, the observations were shown that higher concentrations of chemical agents and metallic salts inhibit enzymes activity in a maximum potential level.

\section{Conflict of Interest}

The authors have no conflict of interest.

\section{Acknowledgement}

The authors gratefully acknowledge the research facilities provided by Food Enzymology Section, Institute of Food Science and Technology (IFST) of Bangladesh Council of Scientific and Industrial Research (BCSIR), Dhaka-1205.

\section{References}

Ajayi, A.A., Ubon-Israel, N.N. and Olasehinde, G.I. (2011). Detection of carrot of extracellular enzymes from diseased carrot. International Journal of Advanced Biotechnology and Research, 2(2), 244249.

Akand, A.H.A.S.M. (2003). Effect of physic-chemical agents on the activity of invertase purified from mango-pulp of himsagar variety. Journal of Applied Science and Technology, 3, 11-16.

Haque, M.Z., Rahman, M.M., Shahjadee, U.F., Rahman, M.M., Rupa, A.Z. and Jalil, M.A. (2017). Amino acids, enzyme activity and effect of chemical agents, metallic salts on the stability of $\alpha$-amylase and protease from Aloe barbadensis Miller. Bangladesh Journal of Botany, 46(4), 1375-1379.

Itohan, A.M., Peters, O. and Kolo, I. (2011). Bacterial contaminants of salad vegetables in Abuj Municipal Area Council, Nigeria. Malaysian Journal of Microbiology, 7(2), 111-114. https:// doi.org/10.21161/mjm.24610

Jahan, M.G.S., Pervin, M.S., Uddin, M.B., Sana, N.K. and Rahman, M.H. (2011). Screening of some enzymes and nutrients in radish (Raphanus sativus L.) root. An Indian Journal of BCAIJ, 5, 296-300.

Jayaraman, J. (1981). Laboratory Manual in Biochemistry. New Delhi, India: Wiley Eastern Ltd.

Khan, M.N.H., Alam, M.Z., Rahman, M.M. and Miah, M.I.H. (2010). Study on the status of pumpkin beetles infesting cucurbits in some area of Bangladesh. Annals of Bangladesh Agriculture, 14(1 and 2),43-52.
Lindley, M.G. (1998). The impact of food processing on antioxidants in vegetable oils, fruits and vegetables. Trends in Food Science and Technology, 9(8-9), 336 -340. https://doi.org/10.1016/S0924-2244(98)000508

Liu, R.H. (2004). Potential synergy of Phytochemicals in cancer prevention: mechanism of action. Journal of Nutrition, 134(12), 3479S-85S. https:// doi.org/10.1093/jn/134.12.3479S

Mahadevan, A. and Sridhar, R. (1982). Methods of Physiological plant pathology. 2nd ed., p. 316. Madras, India: Sivakasi publication.

Nowak, J., Szymczak, J. and Slobodzian, T. (2003). An attempt to determine $50 \%$ toxicity rates of different heavy metals for soil phosphatases. Zeszyty Problemowe Postepow Nauk Rolniczych, 492, 241248.

Odoh, U.E. and Okoro, E.C. (2012). Quantitative phytochemical, proximate/nutritive composition analysis of Beta vulgaris Linnaeus (Chenopodiaceae). Planta Medica, 2012, 78-PI116. https://doi.org/10.1055/s-0032-1320803

Pandey, M., Abidi, A.B., Singh, S. and Singh, R.P. (2006). Nutritional Evaluation of Leafy Vegetables Paratha. Journal of Human Ecology, 19(2), 155-156. https://doi.org/10.1080/09709274.2006.11905871

Enacheshu, M.D. (1995). Food and Vegetable Processing. Food and agriculture organization in the United States. FAO Agricultural Services Bulletin No. 119. Rome, Italy: FAO>

Richard, A.J. and Michael, J.M. (1973). Urease and urea amidohydrolase: Determination of activity in liverworts. Phytochemistry, 12(7), 1675 - 1676. https://doi.org/10.1016/0031-9422(73)80386-3

Rahman, M.M. (2001). Purification, characterization and effect of physico-chemical agents on the stability of amylase from Mango-pulp. Pakistan Journal of Biological Science, 4(1), 98-102. https:// doi.org/10.3923/pjbs.2001.98.102

Wilson, D.B. (2012). Processive and nonprocessive cellulases for biofuel production lessons from bacterial genomes and structural analysis. Applied Microbial Biotechnology, 93, 497-502. https:// doi.org/10.1007/s00253-011-3701-9

World Health Organization (WHO). (1989). Diet, nutrition, and the prevention of chronic diseases. Report of a WHO Study Group meeting held in Geneva from 6-13 March., p. 112. Geneva: WHO.

Wei, X.D., Zou, H.L., Chu, L.M., Liao, B., Ye, C.M. and Lan, C.Y. (2006). Field releases a transgenic papaya effect on soil microbial communities and enzyme activities. Journal of Environmental Sciences (China), 18(4), 734 - 740. 